\title{
YENİLEBİLİR KAPLAMALARIN TAZE KESİLMİŞ MEYVE VE SEBZELERDE KULLANIMI
}

\author{
Çiğdem Yüksel, Derya Atalay*, Hande Selen Erge \\ Bolu Abant İzzet Baysal Üniversitesi, Mühendislik Fakültesi, Gıda Mühendisliği Bölümü, Bolu, Türkiye
}

Geliş / Received: 30.10.2019; Kabul / Accepted: 01.03.2020; Online bask1 / Published online: 27.03.2020

Yüksel, C.., Atalay, D., Erge, H.S. (2020). Yenilebilir kaplamaların taze kesilmiş meyve ve sebzelerde kullanımı. GIDA(2020) 45(2) 340-355 doi: 10.15237/gida.GD19144

Yuksel, C., Atalay, D., Erge, H.S. (2020). Using edible coatings on fresh-cut fruits and vegetables. GIDA(2020) 45(2) 340-355 doi: 10.15237/gida.GD19144

\section{ÖZ}

Taze kesilmiş ürünler, hücrelerin ve dokuların zarar görmesinden dolayı hasat ve tüketim süreci arasında birçok faktöre karşı duyarlıdır. Bu ürünlerde renk değişimi, tekstür bozulması, vitamin kaybı ve mikrobiyal gelişim gibi sorunlar ortaya çıkabilir. Bu problemler nedeniyle, son yıllarda yenilebilir kaplamalar taze kesilmiş ürünlerin raf ömrünün artırllmasinda potansiyel yöntemlerden biri olarak kabul edilmiştir. Yenilebilir kaplamalar; nem ve çözünmüş maddelerin geçişini, gaz alış-verişini, solunum ve oksidatif reaksiyon hızını azaltarak taze kesilmiş meyve ve sebzelerin raf ömrünün ve kalitesinin iyileştirilmesine katkıda bulunabilir. Bu makalenin amacı, taze kesilmiş ürünlerde yenilebilir kaplamaların kullanımını araştırmak ve derlemektir. Bu kapsamda; taze kesilmiş meyve ve sebzelerin önemi, üretimi, yenilebilir kaplamaların bileşimleri, uygulama yöntemleri ve avantaj/dezavantajları değerlendirilmiştir.

Anahtar kelimeler: Taze kesilmiş meyve ve sebze, yenilebilir kaplama, raf ömrü

\section{USING EDIBLE COATINGS ON FRESH-CUT FRUITS AND VEGETABLES}

\begin{abstract}
Fresh-cut products are susceptible to several factors between harvest and consumption period due to damaged cells and tissues. Problems such as color changing, texture loss, shrinkage, vitamin loss and microbial growth etc. may occur in these products. Because of these problems, in recent years use of edible coatings have been considered as one of the potential methods for extending shelf life of these products. Edible coatings may contribute to extend the shelf life and improve quality of fresh-cut fruits and vegetables by decreasing moisture and solute migration, gas exchange, respiration and oxidative reactions rate. The aim of this article is to research and review the using edible coatings on fresh-cut products. In this sense, importance and production of fresh-cut fruits and vegetables, compounds, application methods and advantages/disadvantages of edible coatings were evaluated.

Keywords: Fresh-cut fruit and vegetable, edible coating, shelf life
\end{abstract}

\footnotetext{
* Yazışmalardan sorumlu yazar/Corresponding author:

凶 deryaatalay@ibu.edu.tr @(+90) 3742541000

悬 $(+90) 3742534558$
}

Çiğdem Yüksel; ORCID no: 0000-0001-8506-9899

Derya Atalay; ORCID no: 0000-0003-4536-7239

Hande Selen Erge; ORCID no: 0000-0002-4313-1014 


\section{GİRİ̧}

"Taze" ve "minimum işlenmiş" ürünler Amerika Birleşik Devletleri Tarım Bakanlığ1 (USDA) ve Amerikan İlaç ve Gıda Dairesi (FDA) tarafindan; meyve ve sebzelerin taze bir şekilde kesilmesinden sonra yıkama, paketleme ve buzdolabı sicaklığında muhafaza edilmesi şeklinde tanımlanmaktadır (Beaulieu ve Gorny, 2016; Bhattacharjee vd., 2014). Taze kesilmiş ürünler işlenmiş (yapıda fiziksel değişim) olmasına rağmen çiğ halde; yeme ve pişirme için hazır, dondurulmamıs, 1 sıl işlem uygulanmamıs, katkılar ya da koruyucular ile muamele edilmiş ürünlerdir (Beaulieu ve Gorny, 2016; Bhattacharjee vd., 2014). Taze kesilmiş meyve ve sebzelerin; kabuğu soyulmuş ve/veya kesilmiş, tamamıla kullanılabilir halde olan, tazeliğini sürdürürken besin öğelerini ve lezzeti koruyarak tüketiciye sunabilen paketlenmiş ya da ön paketlenmiş ürünler olarak tanımlandığ1 aktarlmaktadır (Beaulieu ve Gorny, 2016; James ve Ngarmsak, 2010). Ayrıca taze kesilmiş ya da minimum işlenmiş meyve ve sebzelerin, "hafifçe işlenmiş", "kismen işlenmiş", "önceden hazırlanmış" ve "tüketime hazır" gibi kavramlar ile de belirtildiği bildirilmektedir (Temiz ve Ayhan, 2017; Ochoa-Reyes vd., 2019).

Son yillarda, tüketicilerin taze, pratik ve sağliklı gıdalara olan ilgisinden dolayı taze kesilmiş meyve ve sebze endüstrisi hızla artmaktadır. Özellikle taze-kesilmiş elmaların bazı kurumlar, okullar ve kafeteryalarda ve ayrica evlerde popüler atıştırmalık ürün olarak tüketildiği bildirilmektedir (Galindo-Perez vd., 2015; Liu vd., 2016). Ahvenainen (1996) tarafindan Avrupa'da özellikle Fransa ve İngiltere'de minimum işlenmiş meyve ve sebzelerin 1900 'lü yıllarda ortaya çıtığı; Amerika'da 2000 yllında tüm üretimin \%25'inin taze kesilmiş meyve ve sebzelere ait olduğu aktarllmaktadır.

Minimum işlenmiş meyve ve sebze üretiminde besin kalitesinin kaybedilmeden işlenmesi ve tüketici için yeterli bir raf ömrünün sağlanabilmesi en önemli amaçlardır (Ahvenainen, 1996; James ve Ngarmsak, 2010). Meyve ve sebzelerin renk, görünüş, lezzet (tat ve aroma), tekstür ve besin değeri tüketiciler açısından önemli karakteristik özelliklerdir. İlk olarak görünüş, tazelik ve renk; daha sonra tat, aroma ve tekstür önem arz etmektedir (Barrett vd., 2010). Taze kesilmiş ürünlerde, fiziksel işlemler sonucunda enzimatik esmerleşmenin artması, tekstürün bozulması, su kayb1, mikrobiyal bozulmaların hızlanması, istenmeyen tat ve aromaların oluşması raf ömrünü ve kaliteyi etkilemektedir. $\mathrm{Bu}$ nedenle, taze kesilmiş ürünlerde minimal işlemlerin uygulanmas1 gerekmektedir (Ahvenainen, 1996; Temiz ve Ayhan, 2017).

Taze kesilmiş meyve ve sebzelerin üretimine bakıldığında; genellikle hasat, hammadde alımı, ön soğutma, yıkama ve dezenfeksiyon, soyma ve çekirdek çıkarma, kesme, dilimleme, daldırma çözeltileri ile muamele etme, yıkama, soğutma, paketleme ve depolama gibi basamakların yer aldığ1 görülmektedir (Şekil 1) (James ve Ngarmsak, 2010; Bhattacharjee vd., 2014; Temiz ve Ayhan, 2017). Taze kesilmiş meyve ve sebzeye işlenecek olan hammaddenin soğuk ortamda depolanmas1, son ürün kalitesi ve raf ömrü açısından önemlidir. Yıkama işlemi, kesme ve doğrama işlemlerinden önce tank ve kanallarda içilebilir özellikteki su ile yıkanarak gerçekleştirilmektedir. Klorlanmış su, genellikle son yıkamada kullanılmaktadır (James ve Ngarmsak, 2010).

Kabuk soyma işleminde yüksek basınçlı hava, buhar, alkali çözeltiler ve kabuk soyma makinalarından yararlanılmaktadır. Dilimleme, doğrama, parçalama, bölme gibi işlemlerde meyve ve sebzelerin düzgün kesilmiş ve eşit büyüklüklerde olması tüketici açısından önemli sayılmaktadır (Barrett vd., 2010; James ve Ngarmsak, 2010). Kesilmiş meyve ve sebzeler, daha sonra asit, antioksidan, doku yumuşamasını önleyici maddeler ve antimikrobiyal ajanlar içeren daldırma çözeltileri ile işleme tabi tutulmaktadır. Taze kesilmiş meyve ve sebzelerin paketlenmeden önce fazla su ve çözeltilerden uzaklaştırılması gerekmektedir. Son üründe kalan su mikroorganizmaların gelişmesine ve tekstürün bozulmasina sebep olabilmektedir (James ve Ngarmsak, 2010).

Taze kesilmiş meyve ve sebzelerin raf ömürleri çok uzun olmadığı için paketlemeye dikkat 
edilmesi gerekmektedir. Paketlemede genellikle sıcaklık ile şekillendirilmiş ve sert plastikler kullanılmaktadır. Taze kesilmiş meyve ve sebzelerde solunum, paketlemede ve ürün kalitesinde problem oluşturduğu için dikkat edilmelidir. Etilen üreten ürünler ile etilene hassas ürünler aynı ambalajda paketlenmemelidir. Modifiye atmosferde paketleme (MAP), solunum oranını azaltıp bozulmayı yavaşlattığından ve ürün kalitesini geliştirdiğinden dolayı önerilen yöntemlerden biridir (Barrett vd., 2010; James ve Ngarmsak, 2010; Bhattacharjee vd., 2014).

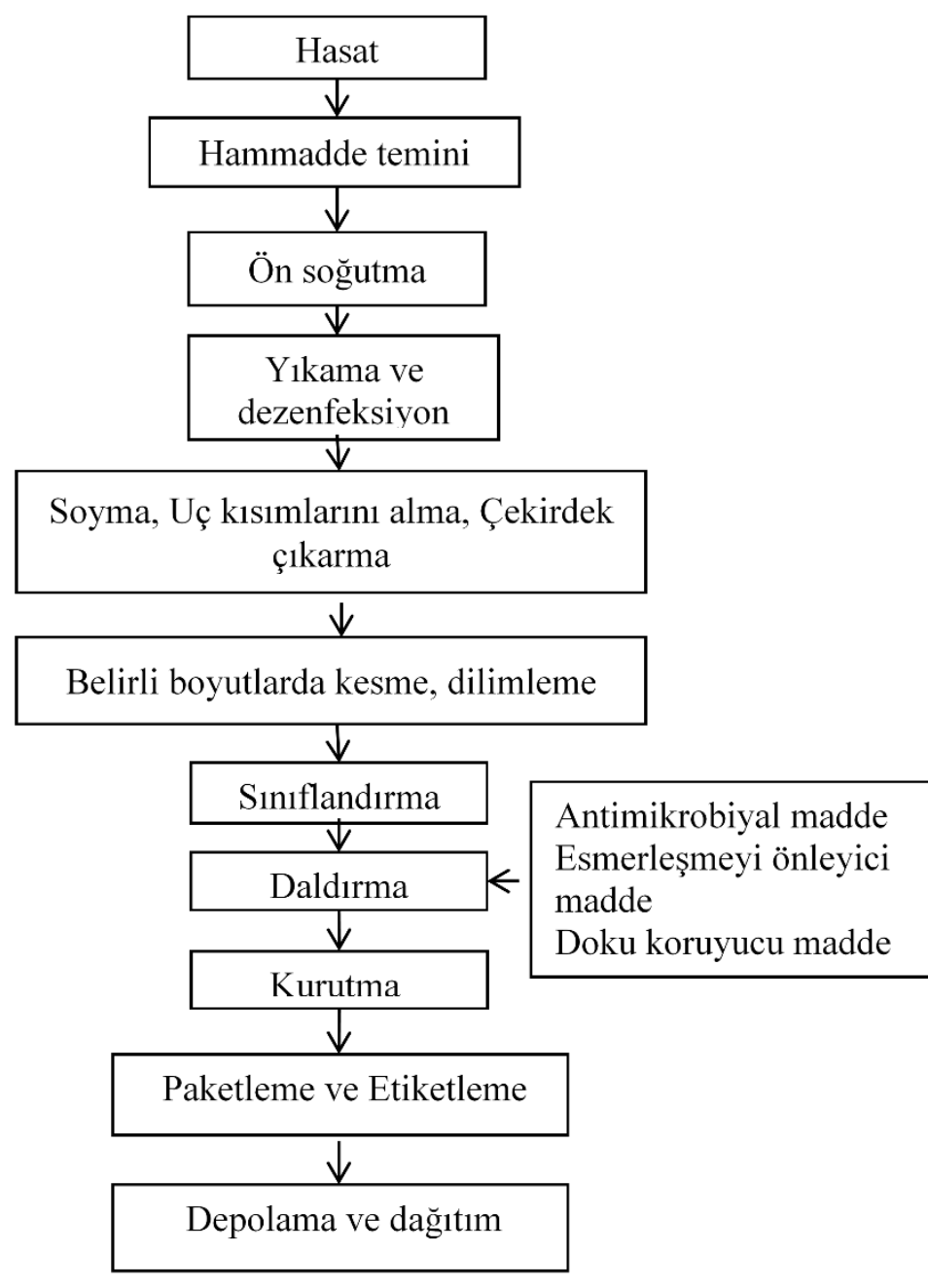

Şekil 1.Taze kesilmiş meyve ve sebzelerin üretim basamakları

\section{TAZE KESİLMİŞ MEYVE VE SEBZELERDE KULLANILAN YENİLEBİLİR KAPLAMALAR}

Meyve ve sebzelerin hasat edilmesinin ardından tüketime kadar geçen sürede fiziksel, kimyasal ve mikrobiyolojik bozulmalar ile kayıplar meydana gelmektedir. Bu durumları engellemek için son dönemlerde araştırmacıların doğal uygulamalara eğilimi olduğu görülmektedir.

Meyve ve sebzelerin, hasattan sonra solunum yapmaya devam ettiği bilinmektedir. Yenilebilir kaplamalar kullanıldığında; dışarıdan oksijen alışverişi sağlanamadığından üründe oksijen tükenmekte ve karbondioksit birikmektedir 
(Guilbert vd., 1996; McHugh ve Senesi, 2000). Daha az oksijenle, etilen üretimi yavaşlar ve suyun fizyolojik kaybı en aza indirilir. Böylece, meyve ve sebzeler uzun süre sağlam, taze ve besleyici kalır ve raf ömürleri neredeyse iki katına çıkar. Meyve ve sebze üzerindeki doğal bariyer ve kaplamanın türü ve miktarı, iç ortamın (oksijen ve karbondioksit) modifiye edilme derecesini ve ağırlık kaybındaki azalma düzeyini etkilemektedir (Arvanitoyannis ve Gorris, 1999).

Doğal kaynaklardan elde edilen yenilebilir kaplamalar; meyve ve sebzelerin yüzeyine uygulanan ince bir tabaka olup meyve ve sebzeyle beraber tüketilebilen malzemelerdir. $\mathrm{Bu}$ kaplamalar, meyve ve sebze için duyusal özellikleri korumakta, ilave edilen aktif bileşiklerle gıdanın besin değerini artırmakta ve kalitesini iyileştirmektedir (Serrano vd., 2015; Ochoa-Reyes vd., 2019).

\section{Yenilebilir Kaplamaların Tanımı ve Tarihi}

Yenilebilir kaplamalar; nem ve oksijene karşı bir bariyer sağlayan, ürün yüzeyine uygulanan ince tabaka yenilebilir özellikte malzemelerdir (Ncama vd., 2018). Yenilebilir filmlerin ve kaplamalarin hazırlanmasinda kullanilan malzemelerin; Amerikan Gida ve İlaç Kurumu (U.S. Food and Drug Administration, FDA) tarafindan onaylanmış genellikle güvenilir (GRAS; Generally Recognized as Safe) ve ilgili yönetmeliklere uygun olmas1 gerekmektedir (Raghav vd., 2016; Kurek vd., 2017).

Meyvelerin balmumu ile kaplanmas1, 12. yüzyllın başlarında popüler olan eski yöntemlerden biridir. Bu yöntemin; Çin'de, limon ve portakallarda su kaybını geciktirmek için uygulandığı bilinmektedir (Raghav vd., 2016; Hassan vd., 2018). Ayrica, mumla kaplanmış meyvelerin mumla kaplanmayan meyvelere kiyasla daha uzun süre depolanabileceği bildirilmiştir. 1930 yılında sıcak eriyik parafin mumları, elma ve armut gibi taze meyvelerde yenilebilir kaplama olarak kullanılmaya başlanmıştır. Daha sonra "laring" olarak adlandırılan yağ kaplaması İngiltere'de popüler hale gelmiştir. 15. yy başlarından bu yana baz1 gidalarda görünüm ve kaliteyi muhafaza etmek için soya sütünden kaynatılarak elde edilen
Yuba isimli film, Asya'da halen kullanılmaktadır. 16. yy'dan bu yana etlerde görünümü iyileştirmek ve büzülmeyi engellemek için yağ ile kaplama uygulanmaktadır. 19. yy'da ceviz, badem ve findık gibi yemişlerin oksidasyonunu ve bozulmasını önlemek için sükrozdan elde edilen yenilebilir kaplamanın kullanıldığ bilinmektedir (Dursun ve Erkan, 2009).

\section{Yenilebilir Kaplamaların Özellikleri}

Yenilebilir kaplamanın özellikleri, molekül büyüklerine ve kimyasal yapılarına bağlıdır (Arvanitoyannis ve Gorris, 1999; Dhall, 2013; Raghav vd., 2016; Ncama vd., 2018).

Kaplama materyalinin; suya dayaniklı olması, yeterli düzeyde ürünü kaplayabilmesi, gaz geçirgenliğini optimumda tutmasi gerekmektedir. Ayrıca, kaplama materyali; su buharı geçirgenliğini azaltmalı, görünümü iyileştirmeli, yapısal bütünlüğü korumalı, mekanik kullanım özelliklerini iyileştirmeli, aktif maddeleri (antioksidanlar, vitaminler, vb.) taşımalı ve uçucu lezzet bileşiklerini muhafaza etmelidir (Raghav vd., 2016; Ncama vd., 2018). Belirtilen bu özelliklerin dışında kaplama materyali; dekompozisyon olmadan $40^{\circ} \mathrm{C}^{\prime}$ nin üzerinde eriyebilmeli, kolay emülsifiye olmalı, yapışkan olmamalı, kurutmaya karşı dirençli olmalı, taze meyve veya sebzenin kalitesini olumsuz etkilememeli, düşük viskoziteye sahip, ekonomik, saydam olmalı ve hafif bir basinca dayanabilmelidir (Arvanitoyannis ve Gorris, 1999; Dhall, 2013).

\section{Yenilebilir Kaplamaların Avantajları ve Dezavantajları}

Yenilebilir kaplamaların, meyve yüzeyine parlaklık kazandırarak dıș görünümü iyileștirme, ağırlık kaybını azaltma, meyve sertliğini koruma ve taze görünümü koruma, solunum ve etilen üretim oranını azaltarak olgunlaşmayı geciktirme gibi avantajları vardır. Meyve ve sebzeleri depolama bozukluklarına karşı korumaktadır. Ayrıca, hasat sonrası kimyasal işlemler için dayanıklılık sağlamakta; aroma bileşiklerini, antioksidanlanı, pigmentleri, esmerleşme reaksiyonlarını engelleyen iyonları ve vitaminleri içermekte, sentetik ambalaj malzemelerinin kullanımını 
azaltmakta ve bazı ülkelerde, ambalaj malzemelerinin sevkiyatına harcanan maliyeti azaltma gibi avantajları bildirilmektedir (Dhall, 2013).

Meyve ve sebze yüzeyine uygulanan kalın kaplama, dış ve iç atmosfer arasında arzu edilmeyen bir bariyer haline gelebilmekte ve solunum gazlarının $\left(\mathrm{CO}_{2}\right.$ ve $\left.\mathrm{O}_{2}\right)$ değișimini kisitlayabilmektedir (Hassan vd., 2018). Bu durum da daha fazla karbondioksit, asetaldehit ve etanol üreten anaerobik solunum ile sonuçlanabilir. Yenilebilir kaplamalar genellikle kaplanmış ürün ile tüketildiğinden; antimikrobiyeller, antioksidanlar ve nutrasötikler gibi bileşiklerin dahil edilmesi, tüketici kabulünü etkilememelidir. Bazen bazı esmerleşme önleyici maddelerin yenilebilir kaplamalara dahil edilmesi durumunda, özellikle de $\mathrm{N}$-asetilsistein ve glutatyon gibi yüksek konsantrasyonlarda sülfür içeren bileşiklerin daldırma maddesi olarak kullanımının hoş olmayan bir koku verdiği belirtilmiştir (İyidoğan ve Bayındırlı, 2004). Yenilebilir kaplamalara nutrasötik bileşiklerin (acı tat, büzücü veya tatlandırıcı) eklenmesi tüketicilerin ürünü beğenmemesine neden olabilmektedir (Drewnowski ve Gomez-Carneros, 2000).

Gıda güvenliği açısından, Avrupa Direktifi ve ABD yönetmeliklerine göre yenilebilir kaplamaların; gıda ürünleri, gıda bileşenleri, gıda katk1 maddeleri, gida temas maddeleri veya gida ambalaj malzemeleri olarak sınıflandırılabildiği aktarılmaktadır (Dhall, 2013). Filmi oluşturan tüm bileşenlerin ya da film malzemelerindeki bir fonksiyonel katkı maddesinin gida sinıfinda yer almas1, toksik olmamas1 ve tüm işlem basamaklarının hijyen standartlarını karşılaması gerekmektedir (Guilbert vd., 1996).

Birçok esansiyel yağ; gıda, sağlık ve kişisel bakım endüstrilerinde yaygın olarak kullanılmaktadır ve aynı zamanda GRAS olarak sinıflandırılmaktadır veya gida katk1 maddeleri olarak izin verilmektedir. Bununla birlikte, bazı tüketicilerin koruyucu kaplama kullanımları hakkında endişeleri bulunmaktadır. Birçok yenilebilir kaplama, alerjik reaksiyonlara neden olabilecek maddelerden üretilmektedir. $\mathrm{Bu}$ alerjenler arasında; süt, soya fasulyesi, balık, yer fistığı, findık ve buğday yer almaktadır. Bu nedenle, bir gida üzerinde alerjen içeren bir kaplamanın varlığı da açıkça belirtilmelidir (Dhall, 2013).

\section{Yenilebilir Kaplamaların Bileşimi}

Meyve ve sebzelerin çoğu, yüzeylerinde kütikül adı verilen doğal bir balmumu tabakasına sahiptir. Gida üzerine ek olarak bir kaplama uygulanmas1, bu doğal bariyerin işlevini artırabilmekte veya hasat sonrası işleme sırasında bu katmanın yerini alabilmektedir. Kaplamalar; nem ve gaz alışverişi için kısmi bir bariyer sağlamakta, yapısal bütünlüğü ve uçucu aroma bileşiklerini korumakta ve diğer fonksiyonel gıda bileşenlerini taşıyarak mekanik işleme özelliğini iyileştirmektedir. Proteinler, polisakkaritler, lipitler ve reçineler gibi biyopolimerler, tek başlarına veya kombinasyon halinde kullanilabilen yaygin kaplama malzemelerdir. Biyopolimerlerin fiziksel ve kimyasal özellikleri, ortaya çıkan kaplamaların işlevselliğini büyük ölçüde etkilemektedir (Galus ve Kadzinska, 2015).

Kaplama malzemeleri; genellikle kaplanabilme özelliğine, suda çözünürlüklerine, hidrofilikhidrofobik ve duyusal özelliklerine göre seçilmektedir. Yenilebilir kaplamalar, film oluşturma kabiliyetine sahip malzemelerden üretilmelidir. Film materyalleri, üretim sırasında su, alkol, su-alkol karışımı gibi bir çözücü içinde dağıtılmalı ve çözülmelidir. $\mathrm{Bu}$ işlemde plastikleştiriciler, antimikrobiyal maddeler, mineraller, vitaminler, renk maddeleri veya aromalar eklenebilmektedir. Seçilen polimerin dispersiyonu için $\mathrm{pH}$ değerinin ayarlanması ve/veya çözeltilerin 1sıtılması gibi işlemler uygulanabilmektedir. Daha sonra film çözeltisi istenen sıcaklıkta ve bağıl nemde dökülmekte ve kurutulmaktadır. Film çözeltileri; gıdalara daldırma, püskürtme, dökme, köpükleme, damlatma ve ardından kurutma gibi çeşitli yöntemlerle uygulanabilmektedir (Arvanitoyannis ve Gorris, 1999; Raghav vd., 2016).

Son yıllarda çeşitli meyve/sebzelerde kullanılan kaplama materyalleri ve etkileri Çizelge 1'de verilmiştir. Ayrıca, gidalara uygulanan kaplamalarda kullanılan maddeler detaylı bir şekilde aşağıda açıklanmaktadır. 
Çizelge 1. Çeşitli meyve/sebzelerde kullanılan kaplama materyalleri ve özellikleri

\begin{tabular}{|c|c|c|c|}
\hline Kaplama Materyali & $\begin{array}{l}\text { Kaplanan } \\
\text { Meyve/Sebze }\end{array}$ & Sonuçlar & Kaynakça \\
\hline Kitosan & $\begin{array}{l}\text { Taze kesilmiş } \\
\text { balkabağ1 }\end{array}$ & $\begin{array}{l}\text { Kontrole kiyasla raf ömrü artırılmıştır. } \mathrm{pH} \text { ve renk } \\
\text { değerleri korunmuştur. }\end{array}$ & Soares vd., 2018 \\
\hline Kitosan+Klorofilin & Çilek & $\begin{array}{l}\text { Antimikrobiyal özellik göstererek yüzeydeki maya } \\
\text { ve küf yükü azaltılmıştır. }\end{array}$ & $\begin{array}{l}\text { Luksiene ve } \\
\text { Buchovec, } 2019\end{array}$ \\
\hline Selüloz ve Türevleri & Domates & Solunum hızını yavaşlatmıştır. & Tosati vd., 2015 \\
\hline \multirow{2}{*}{ Nişasta } & Domates & $\begin{array}{l}\text { Ağırlık kaybı azaltılmış ve film konsantrasyonunun } \\
\text { artması ile raf ömrü uzatılmıştır. }\end{array}$ & Begum vd., 2017 \\
\hline & Mung fasülyesi & $\begin{array}{l}\text { Oksijen bariyeri özelliği sebebiyle paketleme } \\
\text { yöntemi olarak önerilmiştir. }\end{array}$ & Rompothi vd., 2017 \\
\hline Aljinat+ Öjenol & Çilek & $\begin{array}{l}\text { Besin değerleri korunmuş ve mikrobiyolojik } \\
\text { bozulma geciktirilmiştir. }\end{array}$ & Guerreiro vd., 2015 \\
\hline \multirow{2}{*}{ Karragenan } & $\begin{array}{l}\text { Taze kesilmiş } \\
\text { balkabağ1 }\end{array}$ & $\begin{array}{l}\text { Kontrole kiyasla duyusal, dokusal ve } \\
\text { mikrobiyolojik özellikleri korunmuştur. }\end{array}$ & Cho vd., 2016 \\
\hline & $\begin{array}{l}\text { Yaban mersini ve } \\
\text { ahududu }\end{array}$ & $\begin{array}{l}\text { Depolama süresince fizikokimyasal özellikler } \\
\text { korunmuştur. }\end{array}$ & Falcó vd., 2019 \\
\hline Pektin + Sitrik asit $+\mathrm{CaCl}_{2}$ & $\begin{array}{l}\text { Taze kesilmiş } \\
\text { elma }\end{array}$ & $\begin{array}{l}\text { Enzimatik esmerleşme geciktirilmiş ve patojenler } \\
\text { üzerine antimikrobiyal özellik göstermiştir. }\end{array}$ & Sanchís vd., 2016 \\
\hline Pektin & Limon & $\begin{array}{l}\text { Solunum hızı kontrol altında tutulmuş ve tekstür } \\
\text { korunmuştur. }\end{array}$ & $\begin{array}{l}\text { Maftoonazad ve } \\
\text { Ramaswamy, } 2019\end{array}$ \\
\hline Aloe Vera & $\begin{array}{l}\text { Taze kesilmiş } \\
\text { şeftali }\end{array}$ & $\begin{array}{l}\text { Duyusal özellikler korunmuş ve ağırlık kayb1 } \\
\text { azaltılmıştır. }\end{array}$ & Hazrati vd., 2017 \\
\hline Jelatin+ Nişasta & Üzüm & $\begin{array}{l}\text { Su buharı geçirgenliği azaltılmış ve tekstür } \\
\text { korunmuştur. }\end{array}$ & Fakhouri vd., 2015 \\
\hline Zein+ Tannik Asit & Guava & $\begin{array}{l}\text { Solunum hızı yavaşlatılmış ve gaz geçirgenliği } \\
\text { önlenmiştir. }\end{array}$ & Santos vd., 2018 \\
\hline $\begin{array}{l}\text { Soya protein }+ \text { Ferulik } \\
\text { Asit }\end{array}$ & $\begin{array}{l}\text { Taze kesilmiş } \\
\text { elma }\end{array}$ & $\begin{array}{l}\text { Enzimatik esmerleşme geciktirilmiş ve meyvenin } \\
\text { sıkılığı artırllmıştır. }\end{array}$ & Alves vd., 2017 \\
\hline Peynir altı suyu & Çilek & $\begin{array}{l}\text { Ağırlık kaybı azaltılmış ancak renk kaybı } \\
\text { yaşanmıştır. }\end{array}$ & Soazo vd., 2015 \\
\hline Soya Proteini+Kitosan & Kay1s1 & $\begin{array}{l}\text { Kontrol örneğine kiyasla kaplanmış örneklerde } \\
\text { tekstür korunmuştur. }\end{array}$ & Zhang vd., 2018 \\
\hline $\begin{array}{l}\text { Ksantan } \\
\text { Zamk1+Sinamik Asit }\end{array}$ & $\begin{array}{l}\text { Taze kesilmiş } \\
\text { armut }\end{array}$ & $\begin{array}{l}\text { Enzimatik esmerleşme geciktirilmiş ve raf ömrü } \\
\text { uzatılmıştır. }\end{array}$ & Sharma ve Rao, 2015 \\
\hline Kitosan+Guar Zamk1 & Mantar & $\begin{array}{l}\text { Kalite, kontrol örneğine kıyasla kaplanmış } \\
\text { örneklerde korunmuştur. }\end{array}$ & Huang vd., 2019 \\
\hline Karnauba Mumu & $\begin{array}{l}\text { Taze kesilmiş } \\
\text { patlican }\end{array}$ & Kaplanmış örneklerde tekstür korunmuştur. & Singh vd., 2016 \\
\hline $\begin{array}{l}\text { Aljinat }+ \text { Asetillenmiş } \\
\text { Monogliserit }\end{array}$ & $\begin{array}{l}\text { Taze kesilmiş } \\
\text { elma }\end{array}$ & $\begin{array}{l}\text { Sık1lı̆̆1 korunmuş ve enzimatik esmerleşme } \\
\text { geciktirilmiştir. }\end{array}$ & $\begin{array}{l}\text { Espino-Diaz vd., } \\
2016\end{array}$ \\
\hline Aljinat+öjenol & Taze kesilmiş kivi & $\begin{array}{l}\text { Kontrole kıyasla film, meyvenin sıkılığını korumuş } \\
\text { ancak mikrobiyal çoğalma önlenememiştir. }\end{array}$ & Gago vd., 2018 \\
\hline $\begin{array}{l}\text { Kitosan+Transsinamald } \\
\text { ehit }\end{array}$ & $\begin{array}{l}\text { Taze kesilmiş } \\
\text { kavun }\end{array}$ & $\begin{array}{l}\text { Solunum hızı yavaşlatılmış ve nem bariyer özelliği } \\
\text { göstermiştir. }\end{array}$ & Lopes vd., 2016 \\
\hline Pektin+esansiyel yağ & Çilek & $\begin{array}{l}\text { Antimikrobiyal özellik ile bakteri çoğalması } \\
\text { önlenmiştir. }\end{array}$ & Abdi vd., 2017 \\
\hline $\begin{array}{l}\text { Kitosan+Kinoa } \\
\text { Proteini }+ \text { Ayçiçek yağ1 }\end{array}$ & Yaban mersini & Maya ve küf gelişimi kısıtlanmıştır. & Abugoch vd., 2015 \\
\hline Nişasta & $\begin{array}{l}\text { Taze kesilmiş } \\
\text { muz }\end{array}$ & $\begin{array}{l}\text { Solunum hızı yavaşlatılmış ve meyve tekstürü } \\
\text { korunmuştur. }\end{array}$ & Thakur vd., 2019 \\
\hline $\begin{array}{l}\text { Kiraz ve Kayısı Ağac1 } \\
\text { Zamk1 }\end{array}$ & $\begin{array}{l}\text { Çilek ve } \\
\text { yenidünya }\end{array}$ & $\begin{array}{l}\text { Meyvelerin duyusal özellikleri ve mikrobiyolojik } \\
\text { kalitesi korunmuştur. }\end{array}$ & Ergin vd., 2018 \\
\hline Soya Proteini+Bal & Ananas & $\begin{array}{l}\text { Mikrobiyal çoğalma geciktirilmiş ve } \\
\text { fenolik bileşikler korunmuştur. }\end{array}$ & $\begin{array}{l}\text { Yousuf ve } \\
\text { Srivastava, } 2019\end{array}$ \\
\hline
\end{tabular}




\section{Polisakkaritler \\ Selüloz ve türevleri}

Bitki hücre duvarlarının yapısal malzemesi olan selüloz, film üretimi için öncelikle sodyum hidroksit ve karbon disülfür karışımı içinde çözülmekte ve daha sonra selofan üretmek için sülfürik aside dönüştürülmektedir (Kurek vd., 2017). Genel olarak, selüloz türevlerinin film oluşturma özelliği yüksektir, ancak büyük ölçekli ticari kullanım için çok pahalıdır. Anhidroglikozun polimer zincirlerinin s1k1 bir şekilde bir araya gelmesi, sulu ortama dirençli olan kristalli bir yap1 oluşmasını sağlamaktadır. Selülozun suda çözünürlüğü, alkali ile artırılabilir, ardindan karboksimetil selüloz (CMC), metil selüloz (MC), hidroksipropil metil selüloz (HPMC) elde etmek için kloroasetik asit, metil klorür, propilen oksit veya hidroksilpropil selüloz (HPC) ile muamele edilmektedir. MC, HPMC, $\mathrm{HPC}$ ve CMC filmlerinin film oluşturma özelliğinin iyi, genellikle kokusuz, tatsız, esnek ve orta mukavemetli, şeffaf, sıv1 ve katı yağlara karşı dirençli, suda çözünür ve orta derecede nem ve oksijen geçirgenliğine sahip olduğu aktarılmaktadır (Cazon vd., 2017; Hassan vd., 2018). Arnon vd. (2015) mandalinalarda; MC, CMC, HPMC ve kitosan kaplama yaparak depolama ve aroma gelişimini incelemişlerdir. İncelenen materyaller arasinda, CMC ve kitosan kombinasyonundan oluşan kaplamaların en iyi performans gösterdiği belirlenmiştir.

\section{Nişasta ve türevleri}

Nişasta; geniş aralıktaki işlevselliği ve düşük maliyeti nedeniyle gida hidrokolloidi olarak kullanılan doğal polisakkaritlerden biridir (Serrano vd., 2015). Nişasta, hem termal hem de mekanik enerjinin uygulanmasiyla bir ekstrüderde işlendiğinde, termoplastik bir malzemeye dönüştürülmektedir. Termoplastik nişastaların üretiminde, plastikleştiricilerin moleküller arası hidrojen bağlarını etkili bir şekilde azaltmaları ve ürün özelliklerine stabilite sağlamaları beklenmektedir. Nişastanın hidrofilik özelliğinden dolayı, su içeriği değiştikçe işleme sırasında ve işlemden sonra nişasta ile ekstrüde edilen malzemelerin performansı değişmektedir (Kurek vd., 2017).
Begum vd. (2017) domateslerin raf ömrünü uzatmak için nişasta bazlı yenilebilir kaplamalar kullanmıştır. Plastikleştirici olarak gliserol eklenmiş farklı konsantrasyonlardaki nişasta çözeltileri uygulamasında, \%1.5'lik nişasta çözeltisinin domates kaplamada en uygun oran olduğu belirtilmektedir. Ayrıca Hint fesleğeni ekstraktının nişasta bazlı yenilebilir kaplamalara eklenmesi ile depolama kalitesinin artırılabileceği de aktarilmaktadir. Thakur vd. (2019) tarafindan yapılan bir çalışmada, muzda hasat sonrası fizyolojik aktivitenin kontrol edilebilmesi amaciyla pirinç nişastasının yenilebilir kaplama olarak kullanılmasının; ağırlık kaybı, titrasyon asitliği, toplam çözünebilir kuru madde içeriği, renk değişimi, solunum ve etilen üretimi gibi parametrelerin incelenmesiyle araştırıldı̆̆1 belirtilmektedir. Kontrol örneğine kıyasla nişasta kaplanmış muz örneklerinde raf ömrünün 12 gün daha uzatılabildiği bildirilmektedir.

\section{Kitin ve kitosan}

Kitosan, 2-amino-2-deoksi- $\beta$-D-glukanın doğrusal bir polimeridir. Selülozdan sonra doğal olarak bulunan ve en büyük biyopolimer olan kitinin deasetilasyonu ile elde edilmektedir. Kabukluların (yengeç ve karides) kabuk bileşeni, omurgasiz hayvanların iskelet maddesi, mantar ve böceklerin hücre duvarı bileşeni olarak ortaya ç1kmaktadır (Kurt ve Zorba, 2005; Dursun ve Erkan, 2009; Kerch, 2015). Kitosanın; floküle edici madde, koyulaştırıcı, gaz seçici zar, kaplama malzemesi, bitkiyi hastalıtan koruyan destekleyici, doku iyileştirici ve antimikrobiyal madde olarak rol oynadığı bildirilmektedir (Dhall, 2013). Kitosan; film oluşturucu özelliği, vitaminler, mineraller gibi diğer maddelerle uyumluluğu nedeniyle taze ürünler için umut verici kaplama malzemelerinden biri olarak düşünülmektedir (Park ve Zhao, 2004; Kerch, 2015; Cazon vd., 2017). Liu vd. (2016) taze kesilmiş elma dilimlerine kitosan, askorbik asit ve kalsiyüm klorürden oluşan kaplama materyali uygulamış ve 10 saat boyunca oda sıcaklığında gözlemişlerdir. Sonuç olarak, kitosan ile birlikte antioksidan ve mineral madde kullanımının meyvenin esmerleşmesini geciktirdiğini belirtmişlerdir. 
Kitosan içeren kaplamaların; olgunlaşmayı geciktirdiği, meyve ve sebzelerin solunum oranlarını azalttığ1, biber, salatalık ve domateslerde ağırlık kaybını, renk solmasını ve maya gelişimini önlediği gösterilmiştir (Serrano vd., 2015)

Kitosan iç atmosferi modifiye edebilen yar1 geçirgen kaplamalar oluşturabilmekte, böylece meyve ve sebzelerde olgunlaşmayı ve solunumu azaltabilmektedir. Kitosan ve kitinin gida ambalajıyla ilgili diğer bir özelliği de, ağır metal iyonlarını absorbe etme yeteneğinin bulunmasıdır. Kitosan kaplama; çilek, salatalık, biber gibi meyve ve sebze ürünlerinde, antimikrobiyal; elma, armut, şeftali ve erik gibi meyve ve sebze ürünlerinde ise genellikle gaz bariyeri olarak kullanılmaktadır (Ferreira vd., 2016). Kitosan esasli kompozit kaplama formülasyonlarının muz, mango ve kırmızı biber gibi meyve ve sebzelerde raf ömrünü uzattığ1 saptanmıştır (Hassan vd., 2018).

\section{Aljinat ve karragenan}

Aljinatlar; düzgün, saydam ve suda çözünebilen film oluşumunu sağlayan polisakkaritlerdir. Aljinat esaslı filmler sıvı ve katı yağlara karşı dayanıklıdır. Ayrıca, diğer hidrofilik polisakkaritler gibi yüksek su buharı geçirgenliğine sahiplerdir. Aljinat kaplamalar, lipit oksidasyonların geciktirebilen oksijen bariyerleridir (Lin ve Zhao, 2007). Minimum işlenmiş havuçlarda ağırlık kaybını ve mikrobiyolojik yükü azalttığ belirtilmiştir. Karragenan içeren kaplamalar; nem kaybını, oksidasyonu veya parçalanmayı azaltmak için taze meyve ve sebzelere uygulanmaktadır (Ferreira vd., 2016). Azarakhsh vd. (2014) taze kesilmiş ananası, limon otu esansiyel yağı ilave edilmiş aljinat ile kaplamıs, taze meyvenin solunum hızının, ağırlık kaybının, toplam bakteri sayısının ve maya-küf sayısının azaldığını aktarmıslardır.

\section{Pektin}

Pektin; B-1,4 bağl1 D-galakturonik asit ünitelerinden oluşan kompleks bir anyonik polisakarittir. Üronik asit karboksiller tamamen (yüksek metoksi pektin) veya kısmen (düşük metoksi pektin) metil ile esterleşmektedir. Yüksek metoksi pektininin film özelliğinin yüksek kalitede olduğu bilinmektedir (Cazon vd., 2017). Narenciye pektini ve amilaz nişastasının plastikleştirilmiş karışımlarının, $180{ }^{\circ} \mathrm{C}^{\prime}$ ye kadar dayanıklı olan esnek filmler sağladığı bildirilmektedir. Nişastanın, polilaktik asitle karıştırılmasıyla oluşturulan nişasta esaslı plastik köpükler, taşıma sırasında şok ve titreşime karşı koruma sağlamak için yağsız dolgu malzemesi olarak kullanılmaktadır (Hassan ve ark., 2018). Rossi Marquez vd. (2017); taze kesilmiş elma, patates ve havuç dilimlerini peynir altı suyu proteini ve pektin ile kaplamış ve transglutaminaz eklemişlerdir. Kaplanmış ve kaplanmamış meyve ve sebze örneklerinin çeşitli özelliklerini, depolama süresince (10 gün) analiz etmişlerdir. Protein ve polisakkarit kaplamaların, protein esaslı kaplamalara kiyasla daha iyi performans gösterdiğini belirtmişlerdir.

\section{Aloe Vera}

Aloe vera jelinin, antifungal aktivitesi ve fonksiyonel bir bileşen olması nedeniyle içecek ve dondurmalarda kullanılmasi, meyve ve sebzeler için yenilebilir bir kaplama malzemesi olarak dikkat çekmiştir. Aloe vera jel esaslı yenilebilir kaplamalar; nem ve sertlik kaybını azaltması, solunum hızını ve olgunlaşma gelişimini kontrol etmesi, oksidatif esmerleşmeyi geciktirmesi ve mikroorganizma çoğalmasını azaltması özelliğiyle tatlı kirazlar ve sofralık üzümlerde kullanılmıştır (Chrysargyris vd., 2016) Chrysargyris vd. (2016) domateslerde farklı konsantrasyonlarda aloe vera jeli uygulayarak domateslerin hasat sonrasi depolanmasında olumlu sonuçlar elde etmişlerdir. $\mathrm{Bu}$ çalışmada, domateste aloe vera jeli uygulamasının etilen üretimini azalttığı, askorbik asit ve toplam fenolik içeriği ile antioksidan aktiviteyi artırdığı, solunum oranı ve ağırlık kaybı ölçümlerinde değişimlerin olmadığı aktarılmaktadır.

\section{Proteinler}

\section{Jelatin}

Jelatinin geniş uygulama alanlarına sahip olması, emülsifiye ve stabilize etme yeteneği, reolojik özellikleri modifiye etme özelliği, su bağlayıcı ve film oluşturucu özellikleri nedeniyledir (Erge ve Zorba, 2018). Genellikle jelatin filmler; \%20-30 jelatin, \%10-30 plastikleştirici (gliserin veya 
sorbitol) ve \%40-70 sudan oluşmaktadır ve ardından kurutularak uygulanmaktadır (Dhall, 2013).

Portakalın raf ömrünü uzatmak amaciyla jelatin (\%5-7), şellak (\%9-11) ve bir çeşit gam maddesinin (\%3.5-4.5) kullanıldığ1 bir çalışmada, kaplanmış tüm portakal örneklerinde parlaklı̆̆ın arttı̆̆1 ve şellak ile kaplanan örneklerde ağırlık ve sıkılık kaybının daha az olduğu belirtilmiştir (Khorram vd., 2017). Ayrıca, depolama süresi artıkça jelatin ve gam ile kaplanan örneklerde çatlamaların olduğu da bildirilmiştir.

\section{Zein}

Mısır zeini, mısırdaki suda çözünmeyen proteinin en önemlisidir. Zeinin film oluşturma özelliği yüksektir ve biyo-bozunabilir filmlerin üretimi için kullanılabilir. Zein kaplamanın, taze domateslerde nem ve sertlik kaybını azalttığı ve renk değişimini geciktirdiği (oksijen ve karbondioksit iletimini azaltma) belirtilmektedir (Dhall, 2013; Raghav vd., 2016). Elde edilen filmlerin kırılgan olduğu ve bu nedenle esnekliği artırmak için plastikleştirici ilave edilmesi gerektiği bildirilmektedir. Plastikleştiriciler; hidrojen bağlarıyla protein polimer zincirleri arasındaki mesafeyi artırarak kaplamalara esneklik sağlamaktadırlar. Gliserol, sorbitol, polietilen glikol, mono-, di- veya oligosakkaritler, yağ asitleri, lipitler ve türevleri gibi plastikleştirici maddeler kaplamanın kırılganlığını azaltarak, esnekliğini ve uzayabilirliğini artırmaktadırlar (Arham vd., 2018; Yerlikaya vd., 2019). Guava meyvesinin zein ile kaplandığı bir çalışmada kaplama ile birlikte olgunlaşmanın yavaşlatıldığı ve ayrica kaplamada zein ile birlikte tannik asit uygulamasının ağırlık azalışı, yumuşama, renk değişimi, etilen üretimi ve oksidatif stres gibi koşulları azaltmada daha etkili olduğu aktarılmaktadır (Santos vd., 2018).

\section{Glüten}

Glütenin yapışkanlı̆̆1 ve elastikiyeti, buğday hamuruna bütünlük kazandırır ve film oluşumunu kolaylaştırır. Yenilebilir filmler, buğday glüteninin sulu etanol çözeltisinin kurutulmasıyla oluşturulmaktadır. Kurutma sırasında oluşan yeni disülfür bağlarının, hidrojen ve hidrofobik bağlarla birlikte buğday glüten film yapısında önemli olduğu düşünülmektedir (Hassan vd., 2018). Glüten filmlerde gliserol gibi plastikleştiricilerin eklenmesi, film esnekliğini artırmak için gereklidir (Arham vd., 2018). Bununla birlikte, sorbitol içeriğinin film mukavemetini, elastikiyeti ve su buharı bariyer özelliklerini azalttığı belirtilmektedir (Dhall, 2013; Yerlikaya vd., 2019).

\section{Soya proteini}

Soya protein konsantratı veya soya protein izolat1, yağı alınmış proteinli gıdalardan ekstrakte edilmektedir (Lin ve Zhao, 2007). Soya proteini (SP) kaplamaları, esnekliği geliştiren bir plastikleştirici olan ve yaygin olarak kullanılan gliserol ve sorbitol eklenerek soya proteini izolatından hazırlanmaktadır (Dhall, 2013; Kurek vd., 2017). SP kaplamalarının, genellikle proteinin doğal hidrofilik yapisına ve hidrofilik plastikleştiricilerin eklenmesine bağlı olarak zayıf nem direncinin olduğu ve su buharına karşı bariyer özelliğinin de düşük olduğu bildirilmektedir (Sharma vd., 2019).

\section{Kazein ve peynir altı suyu}

Peynir altı suyu proteini ve kazein gibi süt proteinleri, sayısız fonksiyonel özelliği nedeniyle yenebilir filmler ve kaplamalar için önemli malzemelerdir (Lin ve Zhao, 2007). Kazeinler, toplam süt proteinlerinin yaklaşı $\% 80$ 'ini karşılamakta ve yoğun intermoleküler hidrojen, elektrostatik ve hidrofobik bağlar oluşturarak sulu çözeltileri yenilebilir film olarak kullanilabilmektedir (Shendurse vd., 2018). Peynir altı suyu proteinleri, uygun şekilde işlendiğinde, saydam özellikte ve esnek yapida filmler oluşturmaktadır. Peynir altı suyu proteinleri hidrofilik olduğundan, iyi bir nem bariyeri değildir. Denatüre edilmiş film çözeltisine plastikleştirici ilavesi, film esnekliğini geliştirmekte, ancak filmlerin su buharı geçirgenliğini artırmaktadır (Yerlikaya vd., 2019). Kazeinat ve peynir altı suyu protein içerikli kaplamaların, kolay uygulanabilir olmasi ve homojen kaplanabilirliğinden dolayı kuru üzüm, dondurulmuş bezelye ve yer fistığ1 gibi küçük yapıdaki gıdalara uygulandığı aktarılmaktadır (Lin ve Zhao, 2007). 


\section{Lipitler}

\section{Balmumu ve yağ içerikli kaplamalar}

Balmumlar1 (karnauba mumu, balmumu, parafin mumu ve diğerleri), 1930'lardan beri taze meyve ve sebzeler için koruyucu kaplama olarak uygulanmaktadır. Balmumu kaplamaların; turunçgil, elma, yeşil domates, salatalık ve kuşkonmaz, fasulye, pancar, havuç, kereviz, patlican, alabaş, bamya, biber, patates, turp gibi meyve ve sebzelerde yaygin kullanıldığ bildirilmektedir. Trigliseritler veya nötr lipitler, balmumlarına kıyasla yüksek polariteleri nedeniyle gıda yüzeyinde sürekli bir stabil tabaka oluşturabilir. Bitkisel yağlardan elde edilen çoğu yağ asidi; GRAS olarak kabul edilir ve yenilebilir kaplamaların hazırlanmasında kullanılan lipit içerikli mineral yağların yerine önerilmektedir (Lin ve Zhao, 2007; Dehghani vd., 2018).

Mum ve yağ esaslı kaplamalar arasinda parafin mumu, kandelilla mumu, balmumu, karnauba mumu, polietilen mumu ve mineral yağ bulunmaktadır (Galus ve Kadzinska, 2015). Mumlar, gaz ve neme karşı bariyer filmler olarak kullanılmakta (Ochoa-Reyes vd., 2019) ve çeşitli meyve sebzelerin yüzey görünümünü iyileştirmektedir. Kalın bir tabaka halinde uygulanırsa, tüketilmeden önce çıkarılmalıdır. Mumlar (özellikle parafin, karnauba, kandellila ve ar1 balmumu) nem bariyeri için kullanılan en yaygin yenilebilir bileşiklerdir (Serrano vd., 2015).

Karnauba mumu-nanokil emülsiyon kaplamanın portakal üzerinde uygulandığı bir çalışmada, karnauba mumu içerisine eklenen nanokilin duyusal özellikleri ve besin kalitesini olumlu etkilediği; depolama boyunca ağırlık kaybını azalttığı bildirilmektedir (Motamedi vd., 2018).

\section{Yağ asitleri ve monogliseritler}

Yağ asitleri ve monogliseritler, kaplamalarda emülsifiye edici olarak kullanılmaktadır. Katı haldeki çoğu lipit, kırılmadan önce gerçek uzunluğunun sadece \%102'sine kadar uzayabilirken, asetillenmiş gliserol monostearat, gerçek uzunluğunun \%800'üne kadar uzatılabilmektedir (Dhall, 2013). Bitkisel yağlar (mısır yağı, zeytinyağı, kolza yağı, ayçiçeği yağı) kolayca temin edilebilen, düşük maliyetli, toksik olmayan ve uçucu olmayan ürünlerdir. Ayrıca tekli doymamış yağ asidi kaynağıdır ve gıda ürünlerinde yenilebilir kaplama olarak kullanımı sağlık açısından faydalıdır (Galus ve Kadzinska, 2015; Perricone vd., 2015).

\section{Emülsiyonlar}

Balmumu esaslı emülsiyon kaplamaların kullanımı, nem bariyer özelliklerinin yüksek olması nedeniyle dikkat çekmektedir. Ancak, ürüne parlaklık kazandırmazlar. $\mathrm{Bu}$ tür mum emülsiyonlarında kullanılan emülsiyonlaştırıcıların çoğu gliserol ve yağ asitlerinin türevleri olarak bilinmektedir. Ticari olarak temin edilebilen bu tür emülsiyonlaştırıcıların örnekleri arasında poligliserol-polistearatlar yer almaktadır (Galus ve Kadzińska, 2015).

\section{Kompozit ve İki Katmanlı Kaplayıcılar}

$\mathrm{Bu}$ tip kaplamalar, üstün nitelikli bir film oluşturmak ve kaplama bileşenlerinin yararlı özelliklerini birleştirmek için yapılmaktadır. Bu kaplamalar; polisakkaritler, protein ve/veya lipitlerin karışımından oluşabilmekte (Günaydın vd., 2017), doğada heterojen olarak bulunabilmektedir. Bu yaklaşım, kullanılan her film sınıfının farklı işlevsel özelliklerini kullanabilmeyi sağlamaktadır. Kompozit filmlerin üretilmesindeki başlica amaç, özel uygulama ihtiyacına göre geçirgenliği veya mekanik özellikleri iyileştirmektir. Bu heterojen filmler; emülsiyon, süspansiyon, ardışı katmanlar halinde (çok tabakalı kaplama ya da filmler) (Dhall, 2013), ya da ortak bir çözücü içinde bir çözelti formunda uygulanmaktadır. Uygulama yöntemi, elde edilen filmlerin bariyer özelliklerini etkilemektedir. Sınırlı ölçüde kullanılmakta olan çift katmanlı kaplamalar; lipit kaplamaların su bariyeri özellikleri, polisakkarit kaplamaların gaz geçirgenlik özellikleri ile birleştirilmektedir (Hassan vd., 2018).

Kaplamaların işlevselliğinin geliştirilmesi için proteinlerin, polisakkaritlerin ve/veya lipitlerin bir araya getirilmesi gibi kompozit veya iki tabakalı kaplamalara olan ilgi giderek artmıştır. Bu durum, her bir kaplama malzemesinin kendine özgü fakat sınırlı işlevlerin birlikte kullanılmalarıyla geliştirilebileceği gerçeğine dayanmaktadır. 
Polisakkaritler ve proteinler doğada polimerik yapıdadır ve hidrofiliktir. Dolayısıyla düşük bağıl nemde oksijen, aroma ve lipit bariyeri olarak iyi kalitede film oluşturmaktadırlar. Bununla birlikte, sentetik nemlendiricilere kıyasla zayıf nem bariyer özelliği gösterirler. Kompozit filmler ve kaplamalarda; polisakkarit veya protein, film bütünlüğünü sağlamakta ve lipit bileşenini tutarak filmin, nem-bariyer özelliğini sağlamaktadır (Dhall, 2013; Yousuf vd., 2018).

Armutta yenilebilir kompozit kaplamalar üzerine yapılan bir çalışmada; hidroksipropil metilselüloz ve zeytinyağı içeren soya protein izolatı kullanıldığı ve kaplanmamış armutlara kıyasla raf ömrünün 2 kat arttığı bildirilmektedir (Dave vd., 2017). Sucheta vd. (2019) tarafindan yapılan basska bir çalışmada kompozit yenilebilir kaplama olarak farklı oranlarda pektin, misır unu ve kırmızı pancar tozu karışımının domateslerde kullanımı araştırlmıştır. Kontrol örneğine göre yenilebilir kaplama uygulanmıs domateslerde raf ömrünün uzatıldığı ve pektin: mısır unu (\%50:50) karısımı ile sadece pektin uygulanan domateslerde en yüksek parlaklığın ve en düşük büzülmenin gözlendiği aktarılmaktadır.

\section{Yenilebilir Kaplamalarda Kullanılan Aktif Maddeler \\ Antimikrobiyel Ajanlar}

Antimikrobiyel bileşiklerin yenilebilir kaplamalarda kullanımı, ürünün güvenliğini artırmak için diğer bir alternatif olarak görülmektedir (Dhall, 2013). Meyve ve sebzelerin antimikrobiyelleri içeren sulu çözeltilere daldırılması, mikrobiyel stabiliteyi artırmanın en pratik yolu olarak bilinmektedir. Bununla birlikte, antimikrobiyal maddelerin gida yüzeyine uygulanmasinda bazı dezavantajların olduğu bilinmektedir. Aktif maddelerin hızla nötralize edilebildiği veya yüzeyden gida ürününe dağılabildiği ve böylece antimikrobiyal bileşiğin etkisinin sinırlanabildiği ileri sürülmektedir (Hassan vd., 2018).

\section{Doku Geliştiriciler}

Pektik enzimler; depolanma sirasinda, meyve dokularında sertlik kaybına neden olmaktadır (Temiz ve Ayhan, 2017). Taze meyvelerde yumuşamayı kontrol etmenin en yaygin yolu, kalsiyum tuzlarının kullanılmasıdır. Kalsiyum iyonlar1 pektik polimerlerle reaksiyona girerek mekanik direnci artıran, böylece olgunlaşmayı geciktiren ve meyve sebzelerde fizyolojik bozuklukları kontrol eden çapraz bağlantılı bir ăg oluşturmaktadır. Ürünün yumuşamasını en aza indirmek için, yenilebilir kaplamaların formülasyonuna doku artırıcılar dahil edilebilir (Dhall, 2013).

\section{Nütrositler}

Bazı araştırmacılar; bazı meyve ve sebzelerin mikro besin elementlerini artırmak için yenilebilir kaplama formülasyonlarına mineraller, vitaminler ve yağ asitlerini dahil etmişlerdir (Salgado vd., 2015). Park ve Zhao (2004) kitosan içeren filmlerin su bariyeri özelliklerinin, film matriksindeki mineral ve $\mathrm{E}$ vitamini konsantrasyonunu artırarak iyileştiğini bildirmişlerdir. Bu çalışma, kitosan içerikli film matrisinin yüksek miktarda mineral veya $\mathrm{E}$ vitamini taşıyabilme kapasitesini göstermiştir. $\mathrm{Bu}$ filmlerin, gıdaların besin değerini artırmak için ambalajlama veya kaplama materyali olarak kullanılabileceğini aktarmışlardır.

\section{SONUÇ}

Günümüzde birçok yenilebilir kaplama bileşiklerinin taze kesilmiş meyve ve sebzelerde kullanıldığ1 bilinmektedir. Ancak; yenilebilir kaplama uygulanmış taze kesilmiş meyve ve sebzeleri ticarileştirmek, yenilebilir kaplamaların tüketime uygunluğunu geliştirmek, ucuz ve kolay ulaşılabilir kaynaklardan elde etmek için daha fazla araştırmaya ihtiyaç duyulmaktadır. İşlevselliğin ve duyusal performansın geliştirilmesi amacıyla yeni kaplama bileşiklerinin ve uygulamalarının önem kazanacağ1 düşünülmektedir.

\section{KAYNAKÇA}

Abdi, S., Roein, Z., Erfanimoghadam, J., Aziznia, S. (2017). Application of pectin coating containing essential oil for increasing quality of strawberry fruit. J Postharvest Technol, 05(4): 83-94.

Abugoch, L., Tapia, C., Plasencia, D., CastroMandujano, O., Lopez, L., Pastor, A., Escalona, V.H. (2015). Shelf-life of fresh blueberries coated with quinoa protein/chitosan/sunflower oil 
edible film. J Sci Food Agric, 96: 619-626, doi:10.1002/jsfa.7132.

Ahvenainen, R. (1996). New approaches in improving the shelf life of minimally processed fruit and vegetables. Trends Food Sci Technol, 7: 179187.

Alves, M.M., Gonçalves, M.P., Rocha, C.M.R. (2017). Effect of ferulic acid on the performance of soy protein isolate-based edible coatings applied to fresh-cut apples. LWT - Food Sci Technol, 80: 409-415,doi:10.1016/j.lwt.2017.0 3.013.

Arham, R., Salengke, S., Metusalach, M., Mulyati, M.T. (2018). Optimization of agar and glycerol concentration in the manufacture of edible film. Int Food Res J, 25(5): 1845-1851.

Arnon, H., Granit, R., Porat R, Poverenov E. (2015). Development of polysaccharides-based edible coatings for citrus fruits: A layer-by-layer approach. Food Chem, 166: 465-472, doi:10.1016/j.foodchem.2014.06.061.

Arvanitoyannis, I., Gorris, L.G.M. (1999). Edible and biodegradable polymeric materials for food packaging or coating assessment. In: Processing foods: quality optimization and process assessment, Oliveira, F.A.R., Oliveira, J.C., Hendrickx, M.E., Knorr, D., Gorris L.G.M., Amerika Birleşik Devletleri: CRC Press LLC,pp. 357-371. ISBN: 08493-7905-9.

Azarakhsh, N., Osman, A., Ghazali, H.M., Tan, C.P., Mohd Adzahan, N. (2014). Lemongrass essential oil incorporated into alginate-based edible coating for shelf-life extension and quality retention of fresh-cut pineapple. Postharvest Biol Technol, 88: 1-7, doi:10.1016/j.postharvbio. 2013.09.004.

Barrett, D.M., Beaulieu, J.C., Shewfelt, R. (2010). Color, flavor, texture, and nutritional quality of fresh-cut fruits and vegetables: Desirable levels, instrumental and sensory measurement, and the effects of processing. Crit Rev Food Sci Nutr, 50(5): 369-389, doi: 10.1080/10408391003626322.

Beaulieu, J.C. Gorny, J.R. (2016). The Commercial Storage of Fruits, Vegetables, and Florist and Nursery Stocks. In: Fresh-Cut Fruits, Gross, K.C., Wang, C.Y., Saltveit, M.,Agriculture
Handbook Number 66. United States Department of Agriculture, Amerika Birleşik Devletleri, pp. 604-623.

Begum, N., Paul, S.K., Kumar, P., Sahu, J.K., Husain, S.A. (2017). Development of tulsi impregnated starch-based edible coating to extend the shelf-life of tomatoes. The Pharm Innov, 6(9): 249-255.

Bhattacharjee, D., Das, A., Dhua, R.S. (2014). Fresh-cut vegetables: A consumer friendly approach. Int J Sci Res, 3(9): 47-50.

Cazon, P., Velazquez, G., Ramírez, J.A., Vazquez, M. (2017). Polysaccharide-based films and coatings for food packaging: A review. Food Hydrocoll, $\quad$ 68: 136-148, doi: 10.1016/j.foodhyd.2016.09.009.

Cho, J. L.Y., Latifah, M.N., Syed Abas, S.A.R., Siti Aisyah, A., Zaulia, O., Azlin, R.N., Pauziah, M., Nur Syafini, G., Hairiyah, M., Habsah, M., Zaipun, M.Z., Nurul Adibah, M. (2016). Extending shelf-life of minimally processed pumpkin with a carrageenan-based coating. III Int. Conf. on Fresh-Cut Produce: Maintaining Quality and Safety: III Int. Conf. on Fresh-Cut Produce: Maintaining Quality and Safety, 175-180 s.

Chrysargyris, A., Nikou A., Tzortzakis, N. (2016). Effectiveness of Aloe vera gel coating for maintaining tomato fruit quality. N Z J Crop Hortic Sci, 44(3): 203-217, doi:10.1080/01140671. 2016.1181661.

Dave, R.K., Ramana Rao, T.V., Nandane, A. S. (2017). Improvement of post-harvest quality of pear fruit with optimized composite edible coating formulations. J Food Sci Technol, 54(12): 3917-3927, doi:10.1007/s13197-017-2850-y.

Dehghani, S., Hosseini S.V., Regenstein, J.M. (2018). Edible films and coatings in seafood preservation: A review. Food Chem, 240: 505-513, doi:10.1016/j.foodchem.2017.07.034.

Dhall, R.K. (2013). Advances in edible coatings for fresh fruits and vegetables: A review. Crit Rev Food Sci, 53: 435-450, doi: 10.1080/10408398.2010.541568. 
Drewnowski, A., Gomez-Carneros, C. (2000). Bitter taste, phytonutrients and the consumer: A review. Am J Clin Nutr, 72:1424-1435, doi:10.1093/ajen/72.6.1424.

Dursun, S., Erkan, N. (2009). Yenilebilir protein filmler ve su ürünlerinde kullanımı. J Fish Sci, 3(4): 352-373, doi: 10.3153/jfscom.2009040.

Erge, A., Zorba, Ö. (2018). Jelatinin fonksiyonel özellikleri ve gida sanayinde kullanımı. Turk $J$ Agric- Food Sci Technol, 6(7): 840-849, doi:10.24925/turjaf.v6i7.840-849.1779.

Ergin, S. Ö., Yaman, H., Dilek, M. (2018). The usage of edible films extracted from cherry and apricot tree gums for coating of strawberry (Fragaria ananassa) and Loquat (Eriobotrya japonica) Fruits. Turk J Agric- Food Sci Technol, 6(5): 561-569, doi:10.24925/turjaf.v6i5.561-569.1768.

Espino-Diaz, M., Molina-Corral, F., Sepulveda, D., Gonzalez-Aguilar, G., Olivas, G. (2016). Alginate coatings containing high levels of isoleucine improve aromatic and standard quality in fresh-cut apple. EurJ Hortic Sci, 81(3): 175-184, doi:10.17660/eJHS.2016/81.3.6.

Fakhouri, F. M., Maria, S., Caon, T., Ignacio, J., Helena, L., Mei, I. (2015). Edible films and coatings based on starch / gelatin: Film properties and effect of coatings on quality of refrigerated Red Crimson grapes. Postharvest Biol Technol, 109: 57-64, doi.10.1016/j.postharvbio.2015.05.015.

Falcó, I., Randazzo, W., Sánchez, G., Lópezrubio, A., José, M. (2019). On the use of carrageenan matrices for the development of antiviral edible coatings of interest in berries. Food Hydrocoll, 92: 74-85, doi:10.1016/j.foodhyd. 2019.01.039.

Ferreira, A.R.V., Alves, V.D., Coelhoso, I.M. (2016). Polysaccharide-based membranes in food packaging applications. Membranes, 6(22): 1-17, doi:10.3390/membranes6020022.

Gago, C., Vieira, A., Guerreiro, A.C., Miguel, M.G.C., Antunes, M.D.C. (2018). Edible coatings enriched with essential oils for extending the shelf-life of 'Hayward' fresh-cut kiwifruit. Proc. IX International Symposium on Kiwifruit, 533$540 \mathrm{~s}$.
Galindo-Perez, M.J., Quintanar-Guerrero, D., Mercado-Silva, E., Real-Sandoval, S.A., Zambrano-Zaragoza, M.L. (2015). The effects of tocopherol nanocapsules/xanthan gum coatings on the preservation of fresh-cut apples: Evaluation of phenol metabolism. Food Biopro Tech, 8: 1791-1799, doi:10.1007/s11947-015-1523y.

Galus, S., Kadzinska, J. (2015). Food applications of emulsion-based edible films and coatings. TrendsFood Sci Technol, 45, 273-283, doi:10.1016/j.tifs.2015.07.011.

Guerreiro, A.C., Gago, C.M.L., Faleiro, M.L., Miguel, M.G.C., Antunes, M.D.C. (2015). The effect of alginate-based edible coatings enriched with essential oils constituents on Arbutus unedo L. fresh fruit storage. Postharvest Biol Technol, 100: 226-233, doi:10.1016/j.postharvbio.2014.09.002.

Guilbert, S., Gontard, N., Gorris, L.G.M. (1996). Prolongation of the shelf life of perishable food products using biodegradable films and coatings. Lebensm Wiss Technol, 29:10-17.

Günaydın, Ş., Karaca, H., Palou, L., Fuente, B., Pérez-Gago, M.B. (2017). Effect of hydroxypropyl methylcellulose-beeswax composite edible coatings formulated with or without antifungal agents on physicochemical properties of plums during cold storage. $J$ Food Qual, 1-9, doi:10.1155/2017/8573549.

Hassan, B., Chatha, S.A.S., Hussain, A.I., Zia, K.M. (2018). Recent advances on polysaccharides, lipids and protein based edible films and coatings: A review. Int Biol Macromol, 109: 1095-1107, doi:10.1016/j.ijbiomac.2017.11.097.

Hazrati, S., Beyraghdar, A., Farhad, K., Zeinolabedin, H., Sadeghi, A.R. (2017). Evaluation of Aloe vera gel as an alternative edible coating for peach fruits during cold storage period. Gesunde Pflanze, 131-137, doi:10.1007/ s10343-017-0397-5.

Huang, Q., Qian, X., Jiang, T., Zheng, X. (2019). Effect of chitosan and guar gum based composite edible coating on quality of mushroom (Lentinus edodes) during postharvest storage. Sci Hortic, 253: 382-389, doi:10.1016/j.scienta.2019.04.062. 
İyidoğan, N.F., Bayındırlı. A. (2004). Effect of Lcysteine, kojic acid and 4-hexylresorcinol combination on inhibition of enzymatic browning in Amasya apple juice. J Food Eng, 62: 299-304, doi:10.1016/s0260-8774(03)00243-7.

James, J.B, Ngarmsak, T. (2010). Processing of freshcut tropical fruits and vegetables: A technical guide, Bangkok: RAP Publication. Food and Agriculture Organization of the United Nations Regional Office for Asia and the Pacific. ISBN 978-92-5106712-3.

Kerch, G. (2015). Chitosan films and coatings prevent losses of fresh fruit nutritional quality : A review. Trend Food SciTechnol, 46(2): 159-166, doi: 10.1016/j.tifs.2015.10.010.

Khorram, F., Ramezanian, A., Hosseini, S.M.H. (2017). Shellac, gelatin and Persian gum as alternative coating for orange fruit. Sci Hortic, 225: 22-28, doi: 10.1016/j.scienta.2017.06.045.

Kurek, M., Scetar, M., Galic., K. (2017). Edible coatings minimize fat uptake in deep fat fried products: A review. Food Hydrocoll, 71: 225-235, doi: 10.1016/j.foodhyd.2017.05.006.

Kurt, Ş., Zorba, Ö. (2005). Kitin (chitin), kitosan (chitosan) ve türevlerinin gidalarda kullanım olanaklar1. Gida, 30(6): 371-378.

Lin, D., Zhao, Y. (2007). Innovations in the development and application of edible coatings for fresh and minimally processed fruits and vegetables. Compr Rev Food Sci F, 6(3): 60-75, doi: 10.1111/j.1541-4337.2007.00018.x.

Liu, X., Ren, J., Zhu, Y., Han, W., Xuan, H., Ge, L., (2016). The preservation effect of ascorbic acid and calcium chloride modified chitosan coating on fresh-cut apples at room temperature. Colloid Surface A, 502: 102-106, doi:10.1016/j.colsurfa.2016.05.018.

Lopes, R., Freitas, M., Andrade, T., Moita, W., Carvalho, D., Montenegro, I., Miranda, A.D. (2016). Chitosan coating with transcinnamaldehyde improves structural integrity and antioxidant metabolism of fresh-cut melon. Postharvest Biol Technol, 113: 29-39, doi:10.1016/j.postharvbio.2015.11.004.
Luksiene, Z., Buchovec, I. (2019). Impact of chlorophyllin-chitosan coating and visible light on the microbial contamination, shelf life, nutritional and visual quality of strawberries. Innov Food Sci Emerg, 52: 463-472, doi:10.1016/j.ifset. 2019.02.003

Maftoonazad, N., Ramaswamy, H. (2019). Application and evaluation of a pectin-based edible coating process for quality change kinetics and shelf-life extension of lime fruit (Citrus aurantifolium). Coatings, 9: 285-299, doi:10.3390/ coatings 9050285.

McHugh, T.H., Senesi, E. (2000). Apple wraps: A novel method to improve the quality and extend the shelf life of fresh-cut apples. J Food Sci,65: 480485, doi:10.1111/j.1365-2621.2000.tb16032.x.

Motamedi, E., Nasiri, J., Malidarreh, T.R., Kalantari, S., Naghavi, M.R., Safari, M. (2018). Performance of carnauba wax-nanoclay emulsion coatings on postharvest quality of 'Valencia' orange fruit. Sci Hortic, 240: 170-178, doi: 10.1016/j.scienta.2018.06.002.

Ncama, K., Magwaza, L.S., Mditshwa, A. (2018). Plant-based edible coatings for managing postharvest quality of fresh horticultural produce: A review. Food PackShelf, 16: 157-167, doi: 10.1016/j.fpsl.2018.03.011.

Ochoa-Reyes, E., Tirado-Gallegos, J.M., TafollaArellano, J.C., Buenrostro-Figueroa, J.J., Rojas, R., Ochoa-Chantaca, A. (2019). Edible Active Coatings for Foods as a Key Factor for Shelf-Life Prolongation. Handbook of Research on Food Science And Technology, Chavez-Gonzalez, M. L., Buenrosto-Figueroa, J. J., Aguilar, C. (ed.), Apple Academic Press, Oakville, Canada, s. 1-42.

Park, S.I., Zhao, Y. (2004). Incorporation of a high concentration of mineral or vitamin into chitosan-based films. J Agric Food Chem, 52: 19331939, doi:10.1021/jf034612p.

Perricone, M., Arace, E., Corbo, M.R., Sinigaglia, M., Bevilacqua, A. (2015). Bioactivity of essential oils: A review on their interaction with food components. Front Microbiol, 6: 1-7, doi: 10.3389/fmicb.2015.00076. 
Raghav, P.K., Agarwal, N., Saini, M. (2016). Edible coating of fruits and vegetables: A Review. Int J Sci Res Modern Educ, 1; 188-204.

Rompothi, O., Pradipasena, P., Tananuwong, K. (2017). Development of non-water soluble, ductile mung bean starch based edible film with oxygen barrier and heat sealability. Carbohydr Polym, 157: 748-756, doi:10.1016/j.carbpol.2016.09.007.

Rossi Marquez, G., Di Pierro, P., Mariniello, L., Esposito, M., Giosafatto, C.V.L., Porta, R. (2017). Fresh-cut fruit and vegetable coatings by transglutaminase-crosslinked whey protein/ pectin edible films. LWT-Food Sci Technol, 75: 124130, doi:10.1016/j.lwt.2016.08.017.

Salgado, P.R., Ortiz, C.M., Musso, Y.S., Giorgio, L., Mauri, A. (2015). Edible films and coatings containing bioactives. Curr Opin Food Sci, 5: 8692, doi:10.1016/j.cofs.2015.09.004.

Sanchís, E., González, S., Ghidelli, C., Sheth, C.C., Mateos, M., Palou, L., Pérez-gago, M.B. (2016). Browning inhibition and microbial control in fresh-cut persimmon (Diospyros kaki Thunb. cv. Rojo Brillante) by apple pectin-based edible coatings. Postharvest Biol Technol, 112: 186-193, doi:10.1016/j.postharvbio.2015.09.024.

Santos, T.M., Filho, M.S.M.S., Silva, E.O., Silveira, M.R.S., Miranda, M.R.A., Lopes, M.M.A., Azeredo, H.M.C. (2018). Enhancing storage stability of guava with tannic acid-crosslinked zein coatings. Food Chem, 257: 252-258, doi:10.1016/j.foodchem.2018.03.021.

Serrano, M., Martínez- Romero, D., Zapata, P.J., Guillén, F., Valverde, J.M., Díaz-Mula, H.M., Castillo, S., Valero, D. (2015). Advances in Edible Coatings. Advances in Postharvest Fruit and Vegetable Technology. Advances in Postharvest Fruit and Vegetable Technology,Wills, B., Golding, J., (Ed.), CRC Press, Dublin, İlanda, s. 147-166.

Sharma, P., Shenin, V.P., Kaur, N., Vyas., P. (2019). Application of edible coatings on fresh and minimally processed vegetables : A review. Int J Vegetable Sci, 25(3): 295-314, doi:10.1080/19315260.2018.1510863.
Sharma, S., Rao, T.V.R. (2015). Xanthan gum based edible coating enriched with cinnamic acid prevents browning and extends the shelf-life of fresh-cut pears. LWT - Food Sci Technol, 62(1), 791800, doi:10.1016/j.lwt.2014.11.050.

Shendurse, A., Gopikrishna, G., Patel, A.C., Pandya, A.J. (2018). Milk protein based edible films and coatings-preparation, properties and food applications. J Nutr Health Food Eng, 8(2): 219-226,doi:10.15406/jnhfe.2018.08.00273.

Singh, S., Khemariya, P., Rai, A., Chandra, A., Koley, T.K.Singh, B. (2016). Carnauba waxbased edible coating enhances shelf-life and retain quality of eggplant (Solanum melongena) fruits. LWT- Food Sci Tech, 74, 420-426, doi:10.1016/j.lwt.2016.08.004.

Soares, A.S., Ramos, A.M., Vieira, É.N.R., Vanzela, E.S.L., de Oliveira, P.M., Paula, D.A. (2018). Vacuum impregnation of chitosan-based edible coating in minimally processed pumpkin. Int J Food Sci Technol, 53(9): 2229-2238, doi:10.1111/ijfs.13811.

Soazo, M., Perez, L., Rubiolo, A. (2015). Prefreezing application of whey protein-based edible coating to maintain quality attributes of strawberries. Food Sci Technol, 50:605-611, doi:10.1111/ijfs.12667.

Sucheta, K., Chaturvedi, K., Sharma,N., Yadav, S.K. (2019). Composite edible coatings from commercial pectin, corn flour and beetroot powder minimize post-harvest decay, reduces ripening and improves sensory liking of tomatoes. Int Biol Macromol, 133: 284-293, doi: 10.1016/j.ijbiomac.2019.04.132.

Temiz, A., Ayhan, D.K. (2017). Enzymes in minimally processed fruits and vegetables. In: Minimally Processed Refrigerated Fruits and Vegetables, Yildız, F., Wiley,. R.C. (ed.), Second Edition, Amerika Birleşik Devletleri: Springer. pp: 93-151. ISBN: 978-1-4939-7018-6.

Thakur, R., Pristijono, P., Bowyer, M., Singh, S.P., Scarlett, C.J., Stathopoulos, C.E., Vuong, Q. V. (2019). A starch edible surface coating delays banana fruit ripening. LWT - Food Sci Technol, 100: 341-347, doi:10.1016/j.lwt.2018.10.055. 
Tosati, J.V., Oliveira, D. De, Lerin, L.A., Sarantópoulos, C.I.G.L., Monteiro, A.R. (2015). Respiration rate of cherry tomatoes and gas permeability of hydroxypropylmethyl cellulosebased coating. Int J Emerg Technol Adv Eng, 5(3): 281-287.

Yerlikaya, P, Yatmaz, H.A, Topuz, O.K. (2019). Applications of Edible Films and Coatings in Aquatic Foods, Innovative Technologies in Seafood Processing. Özoğul, Y. (baş ed.), CRC Press, pp.7186

Yousuf, B., Srivastava, A.K. (2019). Impact of honey treatments and soy protein isolate-based coating on fresh- cut pineapple during storage at $4^{\circ} \mathrm{C}$. Food Pack Shelf, 21:1-9, doi:10.1016/j.fpsl.2019.100361.
Yousuf B., Qadri, O.S., Srivastava, A.K. (2018). Recent developments in shelf-life extension of fresh-cut fruits and vegetables by application of different edible coatings: A review. $L W T$ - Food Sci Technol, 89: 198-209, doi: 10.1016/j.lwt.2017.10.051.

Zhang, L., Chen, F., Lai, S., Wang, H., Yang, H. (2018). Impact of soybean protein isolatechitosan edible coating on the softening of apricot fruit during storage. LWT - Food Sci Technol, 96: 604-611, doi:10.1016/j.lwt.2018.06.011. 